\title{
Potential Competition Under the Merger Guidehines
}

\author{
Joseph F. Brodley†
}

The 1982 Merger Guidelines ${ }^{1}$ give more enforcement emphasis to potential competition mergers than to any other type of non-horizontal merger. This emphasis reflects the basic theme of the Guidelines-to prevent market structures likely to facilitate collusion. Mergers reducing potential competition in oligopolistic markets raise collusive risks because they may diminish both actual and perceived increases in market rivalry through new entry. Indeed, such anticompetitive risks may be intensified if enforcement effectively constrams horizontal mergers, since collusion-minded firms, barred from horizontal acquisitions, could be stimulated to undertake injurious potential competition inergers.

When the authors of the Guidelines turned to potential competition inergers, they confronted the challenge of devising an effective approach for an area where unworkable legal standards had stymied viable enforceinent. The Guidelines are an effort to bring vitality to potential coinpetition merger enforcement by fornulating structural and objective legal criteria. Such an effort is wcll within the appropriate scope of enforcement guidelines, since the deficiency in potential competition inerger enforcement stems from doctrinal madequacy rather than from any judicial repudiation of the underlying antitrust premise. However, in attempting to reorder the enforcement approach to potential competition inergers, the Guidelines have introduced a new and undefined surrogate for potential competition-"entry advantage"- that unless effectively developed could confuse rather than clarify legal analysis.

Part I of this Article considers the present plight of potential competition inerger enforceinent and the inadequate policy justification for this unsatisfactory condition. Part II then describes the criteria for evaluation of potential coinpetition mergers under the 1982 Guidelines. Part III examines the Guidelines' surrogate for potential competition-

$\dagger$ Professor of Law, Boston University. B.A. 1949, University of California, Los Angeles; LL.B. 1952, Yale University, LL.M. 1953, Harvard University. I have benefited from comments by Edward Cooper, Eleanor Fox, and Daniel Rubinfeld, and from research by Paul Demis.

1. U.S. Dep't of Justice, Merger Guidelines, 47 Fed. Reg. 28,493 (1982), reprinted in 71 CALIF. L. REv. 649 (1983) [heremafter cited without cross-reference as Guidelines]. 
entry advantage-and suggests that the legal proof of this condition might utilize the concept of market proximity. ${ }^{2}$ Finally, Part IV applies the analysis of Parts II and III to a recent potential competition case.

I

\section{The Deficiencies of Current Potential Competition MERGER ENFORCEMENT}

Unworkable legal standards have caused a near breakdown in potential competition merger enforcement. Potential competition merger cases have become a morass of imtractable legal issues, touching allbut-unmeasurable economic phenomena, often with heavy emphasis on the subjective testimony of corporate insiders. ${ }^{3}$ The once unitary concept of potential coinpetition has been unnaturally split into two separate legal doctrines-actual potential competition and perceived potential coinpetition. ${ }^{4}$ The first of these-actual potential competition-is the increased rivalry resulting from future market entry. The second--perceived potential coinpetition-is the increased competitive behavior stimulated within the market by firms reacting to the fear of new entry. While the two effects were once seen as differing manifestations of a single concept of potential competition, they have now become distinct legal theories subject to separate evidentiary obstacles.

\section{A. Evidentiary Obstacles}

Potential coinpetition theories have been made subject to such formidable evidentiary burdens that the government appears incapable of nounting a successful potential competition prosecution. In actual potential competition cases the government must prove the probability of actual market entry, a discrete future event, while in perceived potential competition cases the government inust establish that one of the inerging firms was perceived to be a potential market entrant. ${ }^{5}$ In each case, the government must discharge its evidentiary burden without the aid of an ultimate presumption of liability drawn froin the structure of the market. ${ }^{6}$ Adding to the government's litigation burden, the Supreme Court has twice expressed doubt as to the validity of the actual potential competition theory.

Lower court imterpretations of the broad mandate of the Supreme

2. See infra text accompanying note 72 .

3. See generally Brodley, Potential Competition Mergers: A Structural Synthesis, 87 Y ALE L.J. 1 (1977).

4. Id. at 11-12.

5. United States v. Marine Bancorp., 418 U.S. 602, 632-40 (1974).

6. See Brodley, supra note 3, at 17-25 (in only one of the four essential elements of proof in a potential competition case is the government aided by a presumption).

7. 418 U.S. at 639; accord United States v. Falstaff Brewing Corp., 410 U.S. 526, 537 (1973). 
Court in the nine years since United States v. Marine Bancorporation, ${ }^{8}$ the Court's most recent potential competition decision, illuminate the difficulties that afflict potential competition merger enforcement. In no merger case during this period has the government ultimately succeeded. ${ }^{9}$ The government has been unable to sustain its heavy burden of proof on the issues of econoinic conduct and performance, and the proceedings have been replete with subjective as well as objective economic evidence. ${ }^{10}$

\section{Actual Potential Competition}

More specifically, the governunent has been unable to sustain its burden of proof in any actual potential coinpetition case. Courts have required that the following elements be established in an actual potential competition case: (1) the acquiring firm is a probable market entrant; (2) the firm is one of only a very few such entrants; and (3) the hypothesized future entry would have significant procompetitive effects.

Most actual potential coinpetition cases have foundered on the first eleinent-proof that the acquiring firn is a probable entrant, either de novo or by toehold acquisition. The government has not been able to show that the acquiring firm, even if it had the necessary resources, had the incentive and inotivation to enter the inarket by ineans other than merger. ${ }^{11}$ In recent cases, defendant firms have frequently sought to refute the government's case with subjective evidence, oral or documentary, from the firm's managers purporting to show that they had made an irreversible decision to enter the inarket by inerger only. ${ }^{12}$

Exactimg requirements of proof in the lower courts have added to the government's burden im proving probable entry. Thus, soine courts have held that proof of "eventual entry" into the market or entry within the "reasonably foreseeable future" is not sufficient to establish a reasonable probability of entry; ${ }^{13}$ rather, the government inust establish that entry will occur in "the near future,"14 or within a specified

8. 418 U.S. 602 (1974).

9. The government has ultimately prevailed only in Yamaha Motor Co. v. FTC, 657 F.2d 971 (8th Cir. 1981), cert. denied, 102 S. Ct. 1768 (1982), a joint venture case.

10. See Tenneco, Inc. v. FTC, 689 F.2d 346 (2d Cir. 1982); United States v. Siemens Corp., 621 F.2d 499 (2d Cir. 1980); FTC v. Atlantic Richfield Co., 549 F.2d 289 (4th Cir. 1977); United States v. Black \& Decker Mfg. Co., 430 F. Supp. 729 (D. Md. 1976); British Oxygen Co., 86 F.T.C. 1241 (1975), rev'd and remanded sub nom. BOC Int'l v. FTC, 557 F.2d 24 (2d Cir. 1977); Budd Co., 86 F.T.C. 518 (1975); Beatrice Foods Co., 86 F.T.C. 1 (1975), affd, 540 F.2d 303 (7th Cir. 1976).

11. See, e.g., Tenneco, 689 F.2d at 353-54; Siemens, 621 F.2d at 508.

12. See Siemens, 621 F.2d at 508; Atlantic Richfield, 549 F.2d at 296-98.

13. Republic of Tex. Corp. v. Board of Governors of Fed. Reserve Sys., 649 F.2d 1026, 1047 (5th Cir. 1981); BOC Int'l v. FTC, 557 F.2d 24, 29 (2d Cir. 1977).

14. $B O C, 557$ F.2d at 29. 
"range of months or years." 15 At least one court has required the plamtiff to offer "a persuasive rationale" demonstrating that the acquiring firm would prefer entry over other opportunities for investment or expansion, based on an analysis of comparative profitability. ${ }^{16}$ In the face of these developments the burden of proving probable future entry has become too difficult for the government to sustain.

The government has similarly failed in its attempts to establish the second element-that the acquiring firm is one of only a few other potential entrants. ${ }^{17}$ Proving that the acquiring firm is one of only a few potential entrants puts the government to the added burden of showing low probability of entry by several nonlitigant firms, which defendants typically identify as equally likely potential entrants. This creates a series of minicases that escalates the government's trial difficulties because in each of thein the government must sustam the burden of proof.

In addition, many courts are requiring the government to present explicit and deinonstrative proof as to the third element-that entry, when and if it does occur, would have a deconcentrating or other significant procompetitive effect. ${ }^{18}$ One court recently said that it is not enough for the government to prove that entry by a large firm will "shak[e] things up"; the government must also prove "lasting impact." 19 Another court suggested that the proof must establish not only that the market is presently oligopolistic, but that it "will still be performing oligopolistically at the time of entry," ${ }^{20}$ presumably on the theory that otherwise there is no need to be concerned about preserving potential entrants.

\section{Perceived Potential Competition}

Comparable difficulties have confronted the government's atteinpts to prove a perceived effects case. Recent cases have turned on the subjective perceptions of the inside firms. ${ }^{21}$ Since these perceptions cannot be reliably proved, an inaccurate and ephemeral legal standard has emerged from the case law. The problem is compounded by the necessity of proving not only that the inside firms perceived the acquiring firm as a probable market entrant, but also that sucli perceptions

15. Republic of Tex. Corp., 649 F.2d at 1047.

16. $Y d$.

17. See id. Mercantile Tex. Corp. v. Board of Governors of Fed. Reserve Sys., 638 F.2d 1255, 1267 (5th Cir. 1981); Heublein, Inc., 96 F.T.C. 385 (1980).

18. See Republic of Tex. Corp., 649 F.2d at 1047; Mercantile Tex. Corp., 638 F.2d at 1270.

19. Mercantile Tex. Corp., 638 F.2d at 1270 (citation and footnote omitted).

20. Republic of Tex. Corp., 649 F.2d at 1047.

21. See Tenneco, 689 F.2d at 358; Siemens, 621 F.2d at 508; Black \& Decker, 430 F. Supp. at 769-73. 
disciplined their competitive behavior. ${ }^{22}$ Proof of these facts in any explicit way is not feasible in an adversary proceeding because they involve assessment of the reactions of large and complex organizations, based on the testimony of interested witnesses. ${ }^{23}$ Thus, not only are the testimonial sources apt to be unreliable, but the underlymg phenomena-entry perception and the resulting changes in behavior-appear unmeasurable. For example, unless it is possible to show exactly when the inside firms first began to perceive the acquiring firm as a potential entrant, there is no benchmark of prior collusive behavior against which to compare the present performance of the industry. As a complicating detail, it would be unlikely that the perception, if it occurred, came at once with full force, or at the same time for all inside firms. The perceived entry effect has proved no more tractable than the actual future entry effect.

In the face of these difficulties it is scarcely surprising that the government consistently loses potential competition cases. The government's poor record is all the more significant because one must assume that it lias selected the strongest cases from a field of legal transactions in which the participants are unconstrained by either criminal penalties or any tangible risk of treble daniages. ${ }^{24}$

\section{B. Absence of Policy Justification for Abandonment of Potential Competition Enforcement}

The current breakdown in potential competition enforcement is unjustified in terms of statutory construction, legislative history, or economic theory. Neither the express language of the Clayton Act nor its legislative history inandates such a result; and the neglect of potential competition merger enforcement is not justified by any emerging consensus in economic theory. To the contrary, these factors weigh in favor of a viable and effective enforcement policy.

\section{Statutory Construction}

The courts have consistently held that the Clayton Act bars mergers injurious to potential competition. Although the Supreme Court expressed doubt concerning the validity of the actual potential competition doctrine in two decisions during the 1970 's, ${ }^{25}$ that doubt was ap-

22. See Tenneco, 689 F.2d at 358; Siemens, 621 F.2d at 509 .

23. See generally Brodley, supra note 3, at 15-16 (standard requires addition of a whole new set of witnesses-the managers of other target market firms).

24. In theory damages are available in $\$ 7$ cases, but in practice damage recovery has been all but impossible to obtain due to difficulties of proof. See SEction of ANTITRUst LAW, ABA, Monograph No. 1, Mergers and the Private Antitrust Suit 7-13 (1977).

25. See Marine Bancorp., 418 U.S. at 639; Falstaff Brewing Corp., 410 U.S. at 537. 
parently not based on a careful consideration of the issue, since the inatter had been briefed only tangentially in one of the cases and not at all in the other. ${ }^{26}$ Nor did the Court consider whether such a narrow and strained reading of the Clayton Act would frustrate the purpose of the statute. Since the Sherman Act has been held to cover actual potential coinpetition, ${ }^{27}$ and since the Clayton Act is an incipiency statute designed to prevent anticompetitive acts that are beyond the scope of the Sherman Act, ${ }^{28}$ courts would frustrate the purpose of the Clayton Act if they effectively prevented litigants from bringing potential competition suits under the Clayton Act. Moreover, smce the courts, including the Supreme Court, have consistently held that the reduction of actual potential competition by jomt ventures violates the antitrust laws, ${ }^{29}$ the reluctance of the Supreme Court to extend the doctrine to mergers is even more puzzling. Indeed, Professor Turner, one of two leading section 7 scholars who had initially expressed doubts about the application of the Clayton Act to actual potential competition, ${ }^{30}$ no longer questions its applicability. ${ }^{31}$

\section{Legislative History}

The low estate into which potential competition merger doctrine has fallen also appears contrary to what Congress imtended. It is well known that in amending the Clayton Act in 1950, Congress focused on horizontal inergers as the prime target for intensified enforcement be-

26. The issue was not briefed at all in Falstaff and only tangentially in Marine Bancorp. See Brief for Appellees at 67-71, Marine Bancorp.; Brief for Appellant at 29-31, Marine Bancorp.; Brodley, supra note 3, at 46 \& n. 177.

27. See American Tobacco Co. v. United States, 328 U.S. 781, 809 (1946); United States v. Trenton Potteries Co., 273 U.S. 392, 397 (1927); Standard Oil Co. v. United States, 221 U.S. 1, 74 (1911); United States v. Aluninuin Co. of Ans., 148 F.2d 416, 427-28 (2d Cir. 1945).

28. See S. ReP. No. 1775, 81st Cong., 2d Sess. 5 (1950) [hereinafter cited as Senate RePORT]; see also Bok, Section 7 of the Clayton Act and the Merging of Law and Economics, 74 HARv. L. REv. 226, 255 (1960) ("if one thing is clear fron the legislative history, it is that section 7 was intended to reach well beyond the Sherman Act") (footnote omitted).

29. See, e.g., United States v. Penn-Olin Chein. Co., 378 U.S. 158 (1964); Timken Roller Bearing Co. v. United States, 341 U.S. 593 (1951); United States v. Paramount Pictures, 334 U.S. 131 (1948); Consolidated Gas Elec. Light \& Power Co. v. Pennsylvania Water \& Power Co., 194 F.2d 89 (4th Cir.), cert. denied, 343 U.S. 963 (1952); United States v. Minnesota Mining \& Mfg. Co., 92 F. Supp. 947 (D. Mass. 1950), modified on other grounds, 96 F. Supp. 356 (D. Mass. 1951); United States v. National Lead Co., 63 F. Supp. 513 (S.D.N.Y. 1945), aff'd, 332 U.S. 319 (1947).

30. See Rahl, Applicability of the Clayton Act to Potential Competition, 12 ABA SEC. ANTITRUST L. 128, 142-43 (1958); Turner, Conglomerate Mergers and Section 7 of the Clayton Act, 78 HARV. L. REV. 1313, 1379-83 (1965).

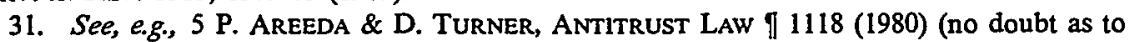
apphicability). The potential conpetition doctrine has been consistently upheld by the FTC, an agency with primary responsibility for enforcement of the Clayton Act. See, e.g., Brunswick Corp., 3 TRADE REg. ReP. (CCH) I 21,740 (FTC Aug. 14, 1980); Heublein, Inc., 96 F.T.C. 385 (1980). It was recently upheld in Yamaha Motor Co., 657 F.2d at 980, and was recently described as having "logical force" in Mercantile Tex. Corp., 638 F.2d at 1265. 
cause most contemporary mergers had been horizontal, ${ }^{32}$ and because horizontal mergers posed the greatest threat to the economic, political, and social values Congress sought to protect. ${ }^{33}$ It is less widely known that Congress viewed a wide category of potential competition mergers-specifically, market extensions and close product extensions-to be in fact horizontal mergers, and thus within the primary enforcement thrust of the amended Clayton Act. ${ }^{34}$ Strikingly, these congressionally viewed "horizontal mergers" comprise almost all the potential competition mergers of possible enforcement concern today.

The congressional usage reflects a longrun view of the goals of merger policy. Congress sought not simply to protect present or shortrun competition-the emphasis im many recent judicial decisions-but to promote competitive market structures over the long run. ${ }^{35}$ Congress defined competitively significant potential competition mergers as horizontal because over time the distimction between direct and potential competition blurs. As the time frame expands, the probability that firms in closely adjacent or proximate markets will meet as competitors increases, because market boundaries shift, and because firms tend naturally to expand into adjacent markets.

The view in Congress that market extension and close product extension mergers were essentially horizontal also accords witl two fundamental congressional policies. The first is the traditional economically based policy of promoting direct market rivalry. The second-primarily noneconomic in its orientation-seeks to prevent the undue concentration of economic authority. ${ }^{36}$ Potential competition mergers, like horizontal mergers, affect the viability of botli policies.

In a recent potential competition decision, the Fifth Circuit recognized the duality of antitrust values motivatimg Congress. Remandimg a merger to the Federal Reserve Board for additional consideration, the court instructed that in evaluating the effects of the merger, the Board need not limit its consideration to economic efficiency, but might also take into account the gam from "dispersal of discretionary eco-

32. See H.R. Rep. No. 1191, 81st Cong., 1st Sess. 2-3 (1949) [hereinafter cited as HousE REPORT]; see also FTC, REPORT OF THE FEDERAL TRADE COMMISSION ON THE MERGER MoveMENT 29 (1948) (horizontal mergers more important than all other types combimed in each of the major mining and manufacturing groups).

33. See Senate RePORT, supra note 28, at 3; House RePORT, supra note 32, at 3-5.

34. See Brodley, supra note 3 , at $43 \&$ n.166 (legislative history indicates that Congress intended a broader meaning for horizontal inergers than that used by the courts).

35. See SENATE REPORT, supra note 28, at 4-5; House REPORT, supra note 32, at 2; 96 CONO. REC. 16,506-07 (1950) (statement of Sen. O'Co1mor); id. at 16,450 (statement of Sen. Kefauver); 95 CONG. REC. 11,493 (1949) (statement of Rep. Carroll); see generally Brodley, supra note 3 , at $40-45$.

36. See Bok, supra note 28, at 234-38; Brodley, supra note 3, at 40-45. 
nomic authority," a particularly vital concern for banking mergers. ${ }^{37}$

\section{Economic Theory}

The neglect of potential competition merger enforcement is also not justified by any persuasive developments im economic theory. While some economists have questioned the theory underlying potential competition, the force and generality of these objections are not sufficient to justify its abandonment in antitrust policy.

The simple economic proposition underlying potential competition merger policy is that in markets where actual competition is weak, potential competition may constrain ohgopolistic behavior, and im addition may ultimately mcrease the competitiveness of the market through eventual new entry. Acquisitions by potential entrants remove this constraint on oligopoly and allow the entrant to obtam a substantial market share without adding productive capacity or expanding output.

Several economic critiques have been made of the potential competition theory. First, some economists urge that the loss of one of a few potential market entrants by merger mcreases, rather than reduces, the prospect of new entry. ${ }^{38}$ This follows because the gain from entry is greatest when a firm can enter the market with the assurance that no other firm will enter. Second, some economists reject the theory of limit pricing-constrained pricing by oligopolistic firms to deter new entry-that underlies the perceived effects doctrine. ${ }^{39}$ These economists question whether an entry deterring price is realistic economic behavior in an oligopolistic market. Third, it is argued that the mcentive for mergers short of monopoly is limited by the fact that the collusive gaim from removal of the threat or actuality of potential entry cannot be fully captured by the merging firms, but is necessarily shared

37. Mercantile Tex. Corp., 638 F.2d at 1271. The court commented further:

Dominant firms daily make decisions affecting not only their shareholders' profits (the presumed primary motivation), but also the hives of their employees, customers and other members of the community. In any economy predicated on the availability of capital, decisions by banking institutions have an especially far-reaching impact on the comununity served. These decisions often have social as well as econounic imphications. The congressional policy underlying the Sherman and Clayton Acts favors a wide dispersal of economic power.

Id. (citations omitted).

38. See Sherman \& Willet, Potential Entrants Discourage Entry, 75 J. Pol. EcoN. 400 (1967).

39. See G. Stigler, The Organization of Industry 19-22 (1968) (theory of limit pricing lacks explanatory power); Joskow, Firm Decision-making Processes and Oligopoly Theory, 87 AM. ECON. A. Proc. 270, 274 (1974) ("monitoring a few rivals is all that is really possible"). But cf. Gaskins, Dynamic Limit Pricing: Optimal Pricing Under Threat of Entry, 3 J. ECON. THEORY 306 (1971) (theoretical analysis proving that monopolist or perfectly functioning cartel would maximize longrun profits by limit pricing). 
across the whole industry. ${ }^{40}$ Fourth, at least one economist has suggested that the acquisition of a leading firm in an ohgopohstic inarket by a substantial acquiring firm might upset tacit agreeinent or ohgopolistic behavior, and thereby increase market competition. ${ }^{41}$ Fifth, some economists assert that a potential competition merger, even if it reduces competition, may be justified by cross-market efficiencies or synergies. ${ }^{42}$ None of the above arguments, however, justifies abandonment of enforcement efforts against potential competition mergers.

The first argument, which asserts that the probability of entry is inversely related to the number of entrants, is more applicable to jomt ventures than to mergers. To permit potential entrants to enter a concentrated market by jomt venture is to prefer an immediate market entry over the mere probability of entry by the parents or other outsider. The inverse relationship argument suggests that this probability is less than might otherwise be thought since in the absence of the joint venture the plurality of existing potential entrants might so reduce the expected individual return from entry as to preclude entry altogether. Under these conditions the certamty of new entry by jomt venture is to be preferred to the merely probable entry of the parents. ${ }^{43}$ The argument loses force, however, when applied to mergers. If barring a merger causes one of a few potential entrants to enter the market de. novo, any loss in potential competition from the reduced imcentive on the part of the remaining potential entrants similarly to enter the market is outweighed by the gam in direct competition from immediate entry. On the other hand, if barring the merger does not lead to de novo entry despite the fact that single firm entry would be profitable, the most likely outcome is that the potential entrants would, by either strategic or cooperative means, including possible formation of a joint venture, solve the problein of securing entry by a simgle firm. ${ }^{44}$

Moreover, even by its own terms, the argument is limited by specialized factual assumptions. It assumes, for example, that a firm's estimates of the costs and benefits of entry are unaffected by the successful entry of another firm; but, in fact, observed successful entry might

40. See Reynolds \& Reeves, The Economics of Potential Competition, in Essays on INDUsTRIal ORganization IN HoNor of Joe S. Bain 207, 213-14 (R. Masson \& P. Qualls eds. 1976).

41. See P. Steiner, MERGERS 258 (1975).

42. See Carter, Actual Potential Entry Under Section 7 of the Clayton Act, 66 VA. L. REv. 1485, 1506-09 (1980); of. Blair \& Peles, Conglomerate Mergers: Efficiency Considerations, in THE CONGlomerate CORPORATION 99 (R. Blair \& R. Lanzillotti eds. 1981) (production complimentaries).

43. See generally Brodley, Joint Ventures and Antitrust Policy, 95 HARV. L. REv. 1521, 1532 \& n.27 (1982).

44. The firms might, for example, reach a tacit understanding to concede entry by one of their number, perhaps in return for some concession by the favored firm in another market or at another time. 
demonstrate its financial feasibility to other firms. Even giving the argument its utmost thrust, the implication for legal policy is to allow potential entrants to enter oligopolistic inarkets by joint ventures, not to sanction mergers. ${ }^{45}$

The issues raised by the second argument against potential competition theory, which questions the realism of limit pricing in oligopolistic markets, go more to magmitude than to existence. If firms can increase their joint profit by exercising pricing restraint, the best assumption in a market economy is that they will engage in limit pricing to at least some extent unless legally constrained. The validity of this assumption is strengthened by the developing economic theory of contestable markets, which has identified the critical importance of potential competition, both threatened and actual, in maintaining effective competitive discipline in monopolistic and oligopolisitic markets. ${ }^{46}$ There are, of course, difficulties in reaching consensus on the limit price. Given the complexity of calculating a longrun entry-limiting price, movements upward to the limit price may nake consensus ainong oligopolists more difficult than would novements to the shortrun monopoly price. At the same time, inovements downward to the limit price may be misinterpreted as competitive challenges by rival oligopolists. On the other hand, unlike collusive price increases, a movement downward from the monopoly price to the limit price does not itself require tacit agreement since it takes only one firm with a substantial market share to force the price down. There is also some empirical support for limit pricing beliavior. ${ }^{47}$ Finally, even if limit pricing behavior were unlikely, actual market entry would still have significant procompetitive effects.

A third argument made by some economists is that the imcentive for potential coinpetition mergers short of monopoly is limited by the

45. In addition, the theory is far from settled and empirical support is slight. On the theoretical level, compare Sherman \& Willett, supra note 38, with Goldberg \& Moirao, Limit Pricing and Potential Competition, 81 J. Pol. EcoN. 1460 (1973) and Kalish, Hartzog \& Cassidy, The Threat of Entry with Mutually Aware Potential Entrants: Comment, 86 J. POL. EcoN. 147 (1978).

46. See Bailey \& Friedlaender, Market Structure and Multiproduct Industries, $20 \mathrm{~J}$. EcoN. LIT. 1024, 1039-46 (1982) (summarizing theory and policy implications generally); Baumol, Contestable Markets: An Uprising in the Theory of Industry Structure, 72 AM. ECON. REV. I (1982); Brodley, Antitrust Policy Under Deregulation: Airline Mergers and the Theory of Contestable Markets, 61 B.U.L. REv. 823, 832-35 (1981) (apphication of theory to airline mergers).

47. Specific instances of limit pricing have been reported. See R. Sultan, Pricing IN THE Electrical Oligopoly 178 (1974) (pricing to maintain inarket share in electrical equipinent industry); Bailey \& Panzar, The Contestability of Airline Markets During the Transition to Deregulation, 44 LAW \& CONTEMP. ProBs. 125 (1981) (evidence that threatened entry provided effective competitive check on pricing behavior in airline market during two-year period); Blackstone, Limit Pricing \& Entry in the Copying Machine Industry, Q. REv. EcoN. \& Bus., Wimter 1972, at 57; Masten, Potential Competition and the United States Chlorine-Alkali Industry, $9 \mathrm{~J}$. INDUs. EcoN. 233 (1961). 
fact that the collusive gain from removal of a potential entrant cannot be fully captured by the merging firms. The same observation, however, could be inade about any horizontal merger, for there also the reduction in competition caused by the merger increases the profitability of all firms in the industry. Nevertheless, in both instances substantial benefits continue to accrue to the acquiring firm from reduced coinpetition.

It is conceivable, as the fourth argument suggests, that an acquisition might destabilize an oligopoly. ${ }^{48}$ But the economic conditions and incentives that led to the original oligopolistic consensus would still be present, and thus the best assumption is that the consensus would eventually be reestablished. ${ }^{49}$

The fifth and final economic argument suggests that a potential competition inerger might produce cross-market efficiencies or synergies. It unay be true that the potential coinpetition merger is more likely to produce efficiencies than pure conglomerate mergers because the products or services of the two firms complement each other. But the argument applies with even greater force to pure horizontal mergers. Although its proponents might argue that the procompetitive benefits of potential competition merger enforcement are weaker than those from horizontal merger enforcement, existing law has already responded to this difference. Horizontal merger policy makes a broad group of mergers unlawful, while potential competition merger policy proscribes only a narrow and egregious group of transactions. Moreover, cross-market complementarities need not be lost altogether if a firm is barred from inerger, smce the firm can still realize such synergies by entering the related market de novo.

\section{Enforcement Feasibility}

Critics have also attacked potential competition theory on the grounds that there are no effective means to identify potential entrants, to rank them in terms of entry probability even if entrants could be identified, or to assess the significance of entry on competition in the inarket. ${ }^{50}$ These objections, however, go to the general feasibility of a Iegal rule for potential competition mergers. This is a subject that the Merger Guidelines address, and to which we now turn.

48. See supra text accompanying note 41 .

49. The Guidelines recognize this, stating that "there is an increased danger that the acquiring firm will choose to acquiesce in monopolization or collusion because of the enhanced profits that would result from its own disappearance from the edge of the inarket." Guidelines $\S \operatorname{IV}(\mathrm{A})(3)(\mathrm{d}) \mathrm{n.43,} 47$ Fed. Reg. at 28,500 n.43, 71 CALIF. L. REv. at $662 \mathrm{n.43.}$

50. See R. Posner, Antitrust Law 122-23 (1976). 
II

\section{THE 1982 MERGER GUIDELINES}

The Merger Guidelines establish a unified legal theory for potential competition mergers that rests on structural criteria and that utilizes objective economic evidence. While the Guidelines recognize two separate theories of potential competition injury-actual and perceived potential competition-and declare that both are to be protected, they do not treat the two effects as separate doctrines, as has been the tendency under the case law. ${ }^{51}$ Instead, the Guidelines evaluate potential competition mergers "under a simgle structural analysis anaIogous to that applied to horizontal mergers." 52

Structural analysis of potential competition mergers first identifies the suspect group of potentially harmful mergers, based on "a set of objective factors." imquiry" with respect to the suspect mergers thus identified to determine whether "the likelihood and magnitude of the possible harin" justify challenging the merger. ${ }^{54}$ During this "more focused" inquiry, the Department is willing to consider "any specific evidence" that may be presented to show that "the inferences of competitive harm drawn from the objective factors are unreliable."ss Thus, the Guidelines call for a two stage inquiry, with the first stage based on an objective analysis of structural factors, while the second is more open ended.

\section{A. First Stage Analysis}

The first stage analysis focuses on four key structural criteria: market concentration, entry conditions, the acquiring firm's relative entry advantage, and the target firm's market share. ${ }^{56}$ These criteria presumptively identify whether the market is sufficiently oligopolistic to require the preservation of potential competition; whether the acquir$\mathrm{mg}$ firm is one of the few most likely market entrants; and whether the target firm is of sufficient size that the foreclosure through merger of eitler de novo entry or toehold acquisition would significantly reduce competition.

\section{Market Concentration}

The first structural criterion is market concentration. Only highly concentrated markets are to be presumed to be "conducive to monopo-

\footnotetext{
51. The development of the case law is described in Brodley, supra note 3, at 10-13.

52. Guidelines $\$ \operatorname{IV}(\mathrm{A})(3), 47 \mathrm{Fed}$. Reg. at $28,499,71$ CALIF. L. REv. at 661.

53. $I d$.

54. Id., 47 Fed. Reg. at 28,500, 71 CALIF. L. Rev. at 661.

55. $I d$.

56. Id. $\S \operatorname{IV}(\mathrm{A})(3)(\mathrm{a})$-(d), $47 \mathrm{Fed}$. Reg. at 28,500, 71 CALIF. L. Rev. at 661-62.
} 
lization or collusion."57 The Guidelines define concentration in terms of a Herfindahl-Hirschman Index (HHI) of 1800, or "somewhat lower" if other factors are present that increase the likelihood of collusion. ${ }^{58}$ The other factors are the saine as those enuinerated for horizontal inergers, and include product and information characteristics as well as such collusion indicators as suspect information exchanges and high profit combined with falling market share.

\section{Entry Conditions}

A second criterion is entry conditions. Only markets in which entry is of at least inoderate difficulty are of enforcement concern. Thus, the Departinent will not oppose a potential coinpetition unerger when entry conditions are easy. As entry becomes more difficult, the Department is increasingly likely to challenge a inerger. The criterion for determining ease of entry is the same as for horizontal inergers: whether a small but nontransitory increase in price would attract new entry. ${ }^{59}$

\section{Entry Advantage of Acquiring Firm}

A third criterion is whether the acquiring firm has an entry advantage in the market to be entered. To satisfy this criterion, the acquiring firm must be one of the few most likely inarket entrants or have a very high individual probability of entering the market. The probability of entry is to be ascertained by considering the "entry advantage" of the acquiring firm. ${ }^{60}$ With one exception, the Department will not challenge a merger unless the acquiring firm is one of no more than three potential entrants with the same or comparable entry advantage. The single exception occurs when the acquiring firm is in the process of entry or is extremely likely to enter. In such cases the Department will treat the merger as if it were a horizontal acquisition, ${ }^{61}$ estimating the inarket share of the acquiring firm in terms of the likely scale of

57. Id. $\S \operatorname{IV}(\mathrm{A})(3)(\mathrm{a}), 47$ Fed. Reg. at $28,500,71$ Calif. L. Rev. at 661.

58. Id.

59. Id. \& IV(A)(3)(b), 47 Fed. Reg. at 28,500, 71 CALIF. L. Rev. at 661 .

60. Id. \& IV(A)(3)(c), 47 Fed. Reg. at 28,500, 71 CALIF. L. REv. at 661-62.

61. Thus, United States v. El Paso Natural Gas Co., 376 U.S. 651 (1964), which the Supreme Court analyzed in potential competition terms, would almost surely be treated as a horizontal merger under the Guidelines. This result is consistent with the Guidelines' market definition provisions, which define the market to include firms not currently selling in the relevant inarket, but which could "easily and economically" do so im response to a small price increase. Guidelines $\S \mathrm{Il}(\mathrm{B})(1), 47$ Fed. Reg. at 28,495, 71 CALIF. L. Rev. at 652.

It should be noted that the inclusive scope of inarket definition under the Guidelines, which includes firms in other product and geographic markets that could sell within the relevant market in response to a small price increase, will sometimes cause a merger previously viewed as bctween potential competitors to be treated as horizontal. These are also the kinds of potential competition mergers in which perceived effects are inost likely to be visible. 
entry. ${ }^{62}$

The introduction of the concept of "entry advantage" is the Guidelines' greatest departure from prior enforcement policy, but the term itself is not defined beyond the Departinent's broad characterization that it is based on a slowing that the acquiring firns are "similarly situated."63 The meaning of this new concept is explored in Part III of this Article, which suggests that the concept of market proximity or inarket similarity has direct relevance in light of the Guidelines' emphasis on objective proof.

\section{Market Share of the Target Firm}

A final criterion is that the target firm must have a market share of more than 5\%. The Department will be imcreasimgly likely to challenge acquisitions as the market share of the target increases above the 5\% threshold, with challenge virtually certain if the percentage reaches $20 \% .64$ Thus, "toehold" acquisitions of firms with a market share of $5 \%$ or less are permitted.

\section{B. Second Stage Analysis}

The above criteria, when present, identify an acquisition as one "in which harmful effects are plausible," focused inquiry mentioned in the Guidelines. The Guidelines provide no guidance on the factors to be considered, but they do indicate that the Department will consider whatever evidence the merging firms deem relevant to show that the adverse inferences drawn from the objective factors are unreliable. ${ }^{66}$ The emphasis on objective evidence found throughout the Guidelines suggests that such presentations will be far inore effective when based on objective rather than subjective evidence, and that the showing will have to be specific and persuasive to overcome the inferences drawn from the objective structural criteria. In brief, the Guidelines have adopted a mode of potential competition analysis that is unitary, structural, and objective.

III

Proof of Entry Advantage

The probability and significance of potential competition under

62. Guidelines $\S \mathrm{IV}(\mathrm{A})(3)(\mathrm{c}), 47 \mathrm{Fed}$. Reg. at 28,500, 71 CALIF. L. Rev. at 661-62. Scale of entry presumably refers to planned capacity since the scale estimate is to be based on "either the firm's own documents or the minimum efficient scale in the industry." Id.

63. Id.

64. Id. $\S \operatorname{IV}(\mathrm{A})(3)(\mathrm{d}), 47$ Fed. Reg. at 28,500, 71 CALIF. L. Rev. at 662.

65. Id. $\S \operatorname{IV}(\mathrm{A})(3), 47 \mathrm{Fed}$. Reg. at $28,500,71$ CALIF. L. Rev. at 661 .

66. Id. 
the Guidelines is determined by ascertaining the "entry advantage" of the outside acquiring firm. Since the Guidelines fail to define this critical concept, its definitive meaning will have to einerge from the Department's evaluations of individual cases. This absence of specificity is a strong indication that the Department has not settled on a fixed definition of entry advantage, perhaps because it wishcs to gam additional experience before committing itself more specifically. This Part suggests that the market proximity approach is the most suitable method for ascertaining a firm's entry advantage.

\section{A. The Defectiveness of Existing Standards of Proof for Probable Entry}

In theory, the most probable market entrant is simply that firm for which the anticipated return from entry (the margm between expected costs and receipts) is greatest, and which by reason of its longrun strategic objectives is most strongly motivated to enter. The motivation factor, however, is necessarily subjective because it is based not on real magnitudes, but on estimates and assessments; it is thus an unsuitable standard on which to base an antitrust enforcement rule. In apparent recognition of this infirmity, the Guidelines have eliminated the subjective elenent from the determination of entry advantage. Creation of a suitable enforcement rule, however, requires the development of workable criteria for the inore objective factor of expected return from entry.

Under conditions of perfect and costless knowledge, it would be possible to quantify the expected costs and revenues that would accrue froin new entry. Such estimates would involve expert appraisals of all relevant costs-production and engineering, distribution, advertising, marketmg, and general overhead-together with projected revenues, based on estimates of market and individual firm demand. ${ }^{67}$ Although complex, the inquiry would be objective in the sense that it would be based on the testimony of imdependent experts who have no imterest in the proceedings apart from their retention as witnesses in the case. ${ }^{68}$

A method similar to this was used in a recent Civil Aeronautics Board merger proceeding, ${ }^{69}$ where the parties introduced direct evidence of anticipated costs and demand. Such estimates are also rehed

67. See Wentz, Mobility Factors in Antitrust Cases: Assessing Market Power in Light of Conditions Affecting Entry and Fringe Expansion, 80 MrCH. L. REv. 1545 (1982) (heroic attempt to demonstrate feasibility of direct estimates of entry barriers).

68. An inquiry is objective if made by a disinterested observer or experimenter, im contrast to a subjective inquiry, in which the observers are participants in the underlying transaction and hence motivated by their own desires and expectations as to the outcome. See F. MACHLUP, THE ECONOMics of Sellers' COMPETITION 103 n.14, 258 \& n.8 (1952).

69. Continental-Western Merger Case, 90 C.A.B. 1 (1981). The appellate and trial proceedings are summarized in Brodley, supra note 46, at 847-58. 
on in utility ratemaking and certification proceedings. But the results of the $\mathrm{CAB}$ merger case were far from satisfactory, ${ }^{70}$ and the investigations used in utility proceedings before a regulatory agency are unsuitable for antitrust litigation.

Courts lack the expertise to resolve complex and speculative factual issues as to future costs and economic conditions. The cases are bound to be burdensome and expensive, especially when competing experts escalate the subtlety of the analysis. Worst of all, the approach would make application of the antitrust standard uncertain and nonpredictive, and, because it would disrupt busmess planning, probably cause more unfavorable results than an overinclusive legal rule. ${ }^{71}$

The alternative method of creating a suitable enforcement rule is to utilize a legal surrogate to identify the entry advantage of the acquiring firm. The identification would be presumptive and thereby shift the burden of proof to the defendants, who are in any event more likely to have the relevant evidence. Recent proposals suggestimg use of the concept of market proximity-the similarity of markets in objective terms-as a surrogate for probable market entry provide useful msight into how the criterion of "entry advantage" can be given predictive content.

\section{B. The Concept of Market Proximity}

Market proximity is a concept of presumptive entry advantage. Two markets are proximate to the extent that a knowledgeable firm in one market possesses the necessary production and inarketing information and other capabilities to operate in the other. Market proximity provides a suitable surrogate for entry advantage because, other factors being equal, there is less risk and therefore less expense involved in entering a familiar market. In a world where information is costly and time scarce, firms do not scan the economic umiverse at random for new investments, but are more likely to move in known directions-into markets with which they already have familiarity. It is therefore reasonable to presume that firms entering adjacent or similar markets have

70. See Brodley, supra note 46 , at $855-58$ (direct estimates of demand, profit, risk, resource availability, and strategic considerations over 17 separate markets led to essentially unreviewable ad hoc determinations).

71. Business goals can frequently be pursued by alternative means. If a merger is not feasible, a joint veuture or long term contractual arrangenent may provide a viable alternative. See Brodley, supra note 43, at 1527-29. But when a business firm cannot anticipate the legal consequences of its actions, it may undertake a transaction that drags it into unwanted litigation when an only slightly inferior alternative was available; or the firm may needlessly avoid a transaction that wonld nltimately be upheld as lawful. See generally FTC v. Procter \& Gamble Co., 386 U.S. 568, 592 (1967) (Harlan, J., concurring) (need of busmess to plan actions with reasonable certainty). 
an "entry advantage," and that the advantage increases as the proximity becomes close. Proximity is determined by: (1) the similarity between the two markets in terms of critical entry characteristics, such as production, marketing, technology, and transactional relations; ${ }^{72}$ and (2) actual observed entry between the two inarkets, or from the outside narket into a market closely similar to the mside market. If according to these criteria the proximity between markets is close, ${ }^{73}$ it can be presumed that the acquiring firm has an entry advantage. Ascertaining that a proximity condition exists requires no hazardous assessment of future cost or demand, but is based on presently existing facts. Thus, the inquiry would not only be objective, but also tractable.

\section{Approaches to Market Proximity}

In recent years two distinct approaches to market proximity have emerged, differing chiefly in their willingness to admit elements additional to proximity itself in assessing entry advantage. Thus, proxinity proposals can be divided into the pure proximity approach and the augmented proximity approach.

\section{The Pure Proximity Approach}

In a 1977 article I suggested a presumptive approach to determining entry advantage based entirely on proximity factors. ${ }^{74}$ Reformulated slightly, iny proposal was that a firm would be presumed to be a significant potential entrant if it is a leading firm in a closely proximate geographic or product market, or if it is a firm of large absolute size (relative to other similarly proximate firms) with significant sales im a closely proximate inarket. Thus, a rebuttable presumption of entry advantage would arise upon a showing of close proximity and large relative size, either in terms of proximate market sales or assets, or total sales or assets. The justification for using the latter factor-large rela-

72. The test is similar to the entry capability concept that was used (along with other factors) in the 1968 Merger Guidelines, as well as in the cases, as the basis for determining probable entry. See U.S. Dep't of Justice, Merger Guidelines-1968, para. 18 (May 30, 1968), reprinted in 2 TRADE REg. Rep. (CCH) I 4510, at 6888 (Aug. 9, 1982). See generally Brodley, supra note 3, at 23. Use of a market similarity (as distinct froun entry capabihity) test einphasizes the objective nature of the determination.

73. Proximity would typically be close, for example, if an acquiring firm already produces the same product in another geographic market; or produces a closely similar product within an accessible geographic market.

74. See Brodley, supra note 3 , at $63-88$. This approach was subsequently recommended by the FTC Bureau of Competition for rulemaking consideration. The Bureau recommended that a rule of pure market proximity be incorporated into a trade regulation rule. The FTC declined, however, to initiate the rulemaking. See Statement of FTC Regarding Staff Recommendation of Advance Notice of Proposed Rulemaking on Potential Competition Mergers, 5 TRADE REG. REP. (CCH) I 50,419 (Oct. 7, 1980). It should be noted that the FTC was then under severe congressional criticism, in part due to previous rulennaking activities. 
tive size-to narrow the field of closely proximate firms is based on both intuitive plausibility (as to the greater investment resources of larger firms) and some empirical evidence. ${ }^{75}$ The presumption should not be absolute, but the showing of entry infirmity that dislodges the entry advantage of the largest proximate firm is best left to the firm itself. The presumption could also be rebutted by proof of the existence of other markets of closer or equivalent proximity, or by other evidence showing that entry was not probable. ${ }^{76}$

\section{The Augmented Proximity Approach}

A presumptive determination of entry advantage may combine proximity with one or more additional factors. Arguably, this leads to a more refined surrogate for entry advantage, but it also complicates the inquiry. Professors Areeda and Turner utilize an augmented proximity approach in their proposed test for identifying potential entrants, as does the Federal Reserve Board in their recently proposed guidelines for potential competition mergers. Both would introduce additional factors, the most important of which involves assessment of the attractiveness of the particular market for entry by the acquiring firm.

\section{a. The Areeda-Turner Test}

Areeda and Turner propose a means for presumptively identifying potential entrants that divides the burden of coming forward with evidence between the government and the defendants. First, the government could establish a presumption that the acquiring firm is a potential entrant based simply on its capacity to enter a market eco-

75. Other things being equal, the larger the firm in either a market or absolute size sense, the greater its capital availability, potential complementarities with the inside market, product diversification, advertising resources, and reputatiou. All of these factors are likely to be advantageous to the firm, as compared with similar but smaller firms. Indeed, an extensive empirical study of new entry by large firms (defined as the 1000 largest industrials) showed that over the 16 year period 1950-1966, de novo entrants possessed these characteristics. See M. Harris, Entry, Barriers to Entry and Limit Pricing 143-47 (1973) (unpublished Ph.D. thesis, available froin Columbia University). But to consider all these factors within a presumptive rule would make the rule unworkably complex, and since under the Harris study large size alone appeared to be a reasonably good predictor of entry, id. at 143,147 , the presumption of entry advantage can rest simply on that factor. Ef. Rose \& Savage, Bank Holding Company De Novo Entry and Market Share Accumulation, 26 ANTITRUST BULL. 753 (1981) (bank holding companies able to acquire greater market shares than independents by de novo entry into concentrated markets).

76. A proximity rule inay be adjusted to the distinct economic characteristics of a particular industry. Thus, in a receut study of airline mergers, I proposed a proximity rule for airline markets based on their particular characteristics as contestable markets. See Brodley, supra note 46. More specifically, I suggested that probable entrants into city-pair airline markets be determined by the objective criteria of whether the putative entrants are existing airlines with either (1) terminals at each end of the city-pair, or (2) a substantial airport "hub" at one end of the city-pair. This would lead to a rebnttable presumption of probable entry, and the burden would shift to the defendant to overcome the presumption. Id. at 863-77. 
nomically attractive to it. Entry capacity would be determined largely by factors of market similarity or proximity (e.g., similar technical resources, marketing skills, and market relationships). ${ }^{77}$ Second, the defendant could then expand the universe of potential entrants by identifying as a putative potential entrant any firm producing either the same product in a different geographic market, or a similar product wherever located. The similarity must exist with respect to the characteristics required for entry. ${ }^{78}$ After these two factors are proved (one by the government, the other by the defendant), the presumptive universe of firms having an entry advantage would be established. It would then be up to the government to narrow the set of presumptive potential entrants by proving that these potential entrants are substantially less likely than the defendant to enter the market. ${ }^{79}$

The Areeda-Turner approach utilizes market proximity in both steps of the presumptive identification of potential entrants, but it places a heavier burden of proof on the government in two ways. First, the defendants are given considerable latitude in expanding the group of potential entrants, because there is no limitation on either the number of similar markets that can be enumerated or on the minimum size or other capabilities of the firms in such markets. ${ }^{80}$ The government must then laboriously eliminate these entry possibilities one by one. Second, and even more importantly, the Areeda-Turner approach requires proof that entry was attractive to the particular acquiring firm-a difficult and ultimately subjective inquiry. ${ }^{81}$ Apparently, it would be necessary to establish that the expected return to the acquiring firm from the entry investment as compared with other investinent opportunities is favorable. ${ }^{82}$ Such an imquiry is intractable and also uimeccessary within the framework of a presuinptive test for potential conipetition, as the Departnient of Justice argued in a recent filing on bank merger guidelines. ${ }^{83}$

77. See 5 P. AREEDA \& D. TURNER, supra note 31, II $1121 \mathrm{c4}-5$, $1121 \mathrm{l}$.

78. Id. I 1123c-e. Under the pure proximity approach, similarity betwcen markets is also established in terms of entry-significant factors since these would necessarily be encompassed in a determination of close proximity. But the entry advantage of the adjacent market location is then confirmed by the observed entry test. See Brodley, supra note 3, at 72-73. The observed entry tcst appears to play no part in the Areeda-Turner approach.

79. See 5 P. AREEDA \& D. TURNER, supra note 31 , I $1123 \mathrm{c}$.

80. By contrast, the pure proximity approach attenpts to limit both categories by restricting the members of the presumptive set to the largest firms in the most closely proximate market or inarkets.

81. See Brodley, supra note 3, at 61-62.

82. 5 P. AREEDA \& D. TURNER, supra note 31 , II $1121 \mathrm{cl},-2,-4$.

83. See Comments of the U.S. Dep't of Justice at 32, In re Statement of Policy on Bank Acquisitions, No. R-0386 (FRB Apr. 9, 1982) (urging exclusion of entry attractiveness from proposed Federal Reserve Board merger guidelines). 


\section{b. The Federal Reserve Board Test}

The Board of Governors of the Federal Reserve Board adopt a simpler approach to the proof of potential competition in their recently proposed guidelines for potential competition mergers. ${ }^{84}$ The Board would presumptively identify probable entrants into economically attractive markets by means of an alınost entirely objective test. Under the proposed guidelines, a banking organization not already located in the market would be presumed a probable entrant based on factors of relative or absolute size. ${ }^{85}$ Thus, probable entry or entry advantage is defined in terms of market proximity and large size either within the market or in absolute terms. A banking market is presumed to be attractive for entry if there are substantial total deposits ( $\$ 250$ million) and an above average growth rate. ${ }^{86}$

The Board of Governors' proposed guidelines represent an example of high tractability and objectivity. In part they reflect the greater ease of applying the potential competition doctrime to market extensions and also the more limited imvestment alternatives open to regulated banking organizations. The proposed banking guidelines provide a striking example of the feasibility of using objective criteria, based on market proximity, to define entry advantage.

IV

\section{Illustration: The TenNeco CASE}

Examination of a recent decision of the Second Circuit, Tenneco, Inc. v. FTC ${ }^{87}$ illuminates the sharp difference in analysis between the Merger Guidelines and the approach prevailing in many lower federal courts. The Department will, of course, have to present its cases to these courts, but enforcement policy is miportant in its own right, because with the lower federal courts taking divergent approaches to potential competition, ${ }^{88}$ the Department's views may well be persuasive to some judges. The issues can be given greater specificity by examining the Tenneco facts as they were viewed by the Second Circuit and as

84. See Policy Statement of the Board of Governors of the Federal Reserve System for Assessing Competitive Factors under the Bank Merger Act and Bank Holding Company Act, 47 Fed. Reg. 9017 (1982).

85. For example, a bank would be presumed to be a probable entrant if it is one of the state's four largest banking organizations, or if it has assets of at least one billion dollars. A somewhat sinaller dollar figure would trigger the presumption in sinall banking states. Id. at 9018.

86. Id. at 9017-18. The other factors in the FRB guidelines are eqnally objective: the market must be highly concentrated, the number of identified potential entrants must be six or less, and the acquired bank must be among the three largest in the market and have at least $10 \%$ of total deposits. Id. The Justice Department criticized the FRB guidelines in certain respects, but in general expressed support. See Comments of the U.S. Dep't of Justice, supra note 83.

87. 689 F.2d 346 (2d Cir. 1982).

88. See supra authorities cited in notes 10-17. 
they would be evaluated under the Merger Guidelines. The latter result is then compared with an analysis under the market proximity approach.

\section{A. Tenneco}

The facts of Tenneco presented one of the strongest cases of potential competition injury in recent years. The merger involved an acquisition in the automotive shock absorber replacement market, a market in which concentration was "extraordinarily high." 89 The four-firm ratio exceeded $90 \%$, the two-firm ratio exceeded $77 \%$, and the HHI exceeded 3000. The target firm, Monroe Auto Equipment, was one of two leading firms of almost equal size in the replacement shock absorber market, with a $38 \%$ market share. The acquiring firm, Tenneco, was the nation's 15th largest industrial corporation and a leading seller of exhaust system parts, a product line closely related to replacement shock absorbers. The target market, in addition to being highly concentrated, seemed clearly ohgopolistic. It had high entry barriers, stable market shares among the top four firms, and generally high profits. The record established that Tenneco had the capability and also the mcentive to enter the market. It previously had negotiated for a manufacturing license arrangement and had acquired a small manufacturing firm that held a sliock absorber patent. ${ }^{90}$ Nevertheless, the Second Circuit in a 2-1 decision rejected application of the actual potential competition doctrime, holding the FTC's findings that Tenneco would have entered the market de novo or by toehold acquisition to be "unsupported speculation."91 The court reasoned that Tenneco had decided in the 1960's and early 1970's not to enter the market, despite the then high profitability of shock absorber manufacturers, ${ }^{92}$ and with earnings now lower, the Commission had no evidence on which to base a finding of probable entry de novo. Similarly, toehold entry was not proved because the asking prices for two toehold firms were excessive, while a third such firm was weak and deteriorating. ${ }^{93}$

The Tenneco court also overturned the Commission's findings that the merger mjured perceived potential competition. While there was "abundant evidence" that the shock absorber "oligopohsts" perceived Tenneco as a potential entrant, the court said that there was insufficient evidentiary support for the finding that such perceptions tempered
89. 689 F.2d at 353.
90. Id.
91. Id. at 353-54.
92. Id. at 354 .
93. Id at 354-55. 
oligopohistic behavior. ${ }^{94}$ More particularly, the Commission had ignored direct contrary evidence by a senior officer of the largest firm in the target market, and had inferred entry perception fron the fact that competition had increased without a clear showing of causal relation. ${ }^{95}$ For these reasons the court held the FTC's findings as to perceived potential competitive also to be erroneous and set aside the Commission's order. ${ }^{96}$

\section{B. Application of the Merger Guidelines to Tenneco}

Application of the Merger Guidelines to the facts in Tenneco indicates that the inerger presents a clear risk of injury to potential competition. First, market concentration in the target shock absorber market registered an HHI value in excess of 3000 , far above the Guidelines' threshold of 1800 at which the Department is "increasingly likely" to challenge a merger. ${ }^{97}$ The concentration finding was further aggravated by the presence of several nonmarket criteria of collusion, such as stable market shares and high profits. ${ }^{98}$ Second, entry into the market was far froin easy. ${ }^{99}$ Under the Guidelines, the Department is increasingly likely to challenge a merger as entry difficulty grows. ${ }^{100}$ Third, the inarket share of the target firm was almost double the $20 \%$ threshold at or above whicl the Department is likely to challenge any inerger that ineets the other conditions. ${ }^{101}$

Finally, the acquiring firm, Tenneco, appeared to have an entry advantage over other firms. While the Guidelimes have not specified what facts would establish an entry advantage, the following facts, characterized in the dissenting opinion as undisputed, appear persuasive: a "strong market affinity and compatibility" existed between the exhaust systein parts market in which Tenneco was engaged and the replacement shock absorber market it sought to enter, ${ }^{102}$ use of coin-

94. Id. at 355 .

95. Id. at 358 .

96. Id.

In a vigorous dissent, Judge Mansfield, himself the author of a major decision of the Second Circuit on potential competition, found the Commission's finding on the presence of a tempering effect to be beyond question. Id. at 361 (Mansfield, J., dissenting). In his view both the circumstantial evidence of "a burst of pro-competitive conduct" by the market leader, $i d$, and the direct evidence by "an obviously biased" member of the four-firm oligopoly, id. at 363 , clearly supported the Commission's findings of a tempering effect. Since the other elements of a perceived entry case were present, Judge Mansfield reasoned that the Commission's finding should lave been sustained.

97. Guidelines § IV(A)(3)(a), 47 Fed. Reg. at 28,500, 71 CalIF. L. REv. at 661.

98. Tenneco, 689 F.2d at 353. Market sliares had stabilized only in recent years.

99. Id. at 350 .

100. Guidelines § IV(A)(3)(b), 47 Fed. Reg. at 28,500, 71 CALIF. L. REv. at 661.

101. Id. $\S \operatorname{IV}(\mathrm{A})(3)(\mathrm{d}), 47$ Fed. Reg. at $28,500,71$ CALIF. L. REv. at 662.

102. Tenneco, 689 F.2d at 359-60 (Mansfield, J., dissenting). 
mon facilities, including shipping, warehousing, and sales installation, was economical and commercially sensible; the technology was overlapping; Tenneco, as the dommant firm im the exhaust systein inarket, had the specific research, production, and marketmg skills to enter the shock absorber market; and finally, Tenneco was the only major inanufacturer in the exhaust system market that was not engaged in the production of shock absorbers. ${ }^{103}$ These facts would seein clearly to establisl 1 an entry advantage for Tenneco not duplicated by any other firm in the exhaust system market, and according to the FTC's finding, not possessed by any firm outside the shock absorber market. ${ }^{104}$

Under the Merger Guidehines, therefore, the Tenneco faets present a compelling case for enforcement investigation. The acquiring firm has a unique entry advantage; and inarket concentration, entry barriers, and market share of the target firm are as high as are ever likely to be encountered in potential coinpetition inergers. Would it be possible nonetheless to overcoine the presumption of enforcement concern based on the "more focused," but otherwise unspecified, second stage imquiry? So long as the Departinent places primary reliance on objective evidence, overcoming this presumption appears unlikely. The objective evidence in Tenneco pointed unambiguously toward merger liability, and it was only by a substantial reliance on subjective evidence that the court of appeals was able to overturn the FTC's exhaustive opimion and findings. ${ }^{105}$ An additional factor that would make the presumption of enforcement concern difficult to overcoune sterns from viewing potential competition as a unitary concept, as einphasized in the Guidelines. ${ }^{106}$ The inference that Tenneco is, in an overall sense, a probable potential entrant into the replacement shock absorber unarket seems more difficult to refute than it would be for the defendants to establish that the government's proof of eacli of the two entry effects, considered imdividually and seriatim, was deficient. Indeed, refutation appears all but impossible on the objective facts presented. ${ }^{107}$

\section{Application of Market Proximity Criteria to Tenneco}

Application of the market proximity approach (particularly pure

103. Id. at 359 .

104. Tenneco, Inc., 3 TRADE Reg. REp. (CCH) If 21,873, at 22,133 (FTC Sept. 23, 1981), rev'd, 689 F.2d 346 (2d Cir. 1982).

105. See, e.g., Tenneco, 689 F.2d at 355 (discussion of perceptions of industry executives).

106. See Guidelines § IV(A)(1), 47 Fed. Reg. at 28,499, 71 CALIF. L. Rev. at 660.

107. Although it inay appear counterintuitive to suggest that overall entry probability could be greater than its two constituent effects-actual entry and perceived entry-it is nevertheless true that under the existing approach to potential competition, no summation takes place at all since each of the two constituent potential competition effects is considered in isolation. By framing the issue in terms of a single overall potential coinpetition probability, the Merger Guidelines make the two entry effects additive for the first time in recent enforcement history. 
proximity) to the facts of Tenneco confirms the validity of the result reached under the Merger Guidelines. Given the strikingly anticompetitive structure of the target shock absorber market in terms of market concentration and entry barriers, the critical issue under a proximity approach-as under the Merger Guidelines-is whether the acquiring firm had an entry advantage. As discussed above, under a proximity approach, market proximity becomes the surrogate for entry advantage. ${ }^{108}$

\section{Application of the Pure Proximity Approach}

Under the pure proximity approach the target market would be deemed closely proximate to the market of the acquiring firm. ${ }^{109}$ Both entry-relevant production similarity and marketing similarity existed in Tenneco. In addition, the market similarity finding was confirmed by observed entry from the proximate market into the target market. Every other major firm in the exhaust system market had already entered the shock absorber market by toehold acquisition. ${ }^{110}$ Thus, simce the two inarkets are closely proximate, the burden would then shift to the merger proponents to show, if they can, that other markets are of closer or equivalent proximity. Indeed the Tenneco defendants attempted to make such a showing, but it was rejected by the FTC in a careful analysis. ${ }^{11}$

The additional condition under the pure proximity approachthat the acquiring firm be a significant potential entrant-is easily satisfied by the facts in Tenneco. Tenneco was both the leading outside firm in the proximate market and was a proximate market firm that ranked among the largest industrial corporations. Accordingly, nnder the pure proximity approach, Tenneco would be identified as a probable and significant market entrant or, in Guidelines' terms, as a firm having significant entry advantage.

\section{Application of the Areeda-Turner Approach}

The analytic result is less certain under the Areeda-Turner approach. Under Areeda-Turner, the threshold showing that the acquiring firm is a potential entrant requires proof not ouly of its capability of market entry, but also proof that market entry is attractive to that firm. Although entry capability is readily shown on the facts previously out-

108. See supra text accompanying notes 74-75.

109. See supra text accoinpanying notes $87-97$ (high inarket concentration, high entry barriers, and large inarket share of target firm).

110. Tenneco, 3 Trade Reg. ReP. (CCH) at 22,140.

111. Id. at 22,149-51. 
lined, ${ }^{112}$ proof of entry attractiveness to Tenneco seems more difficult unless the showing is based solely on objective evidence. In objective terms entry appears attractive to Tenneco because profit rates had been high and because entry would result in production and nnarketing synergies. ${ }^{113}$ But since Areeda and Turner would not exclude subjective evidence, the issue of inarket advantage might be coinplicated by the same problein that contronted the Second Circuit inajority: the diffculty of proving affirmatively that an adverse, fully advised business litigant would find a particular course of action desirable. ${ }^{114}$

The second step in the Areeda-Turner approach would allow Tenneco to expand the universe of potential entrants and eliminate the presumption of entry advantage. Any firm producing a similar product in terms of entry-significant characteristics could be presumptively identified as a potential entrant. Tenneco could immediately identify two other "inajor inanufacturers" of replacement shock absorbers. ${ }^{115}$ It could also plausibly identify several other inarkets as equally similar or proxinnate, such as vehicle manufacturers, foreign shock absorber manufacturers, and vehicle parts inanufacturers. ${ }^{116}$ This would enlarge the set of potential entrants and therefore make Tenneco only one of many "inost likely" entrants. A presumption of entry advantage would thus not obtain, and the burden of persuasion would then be on the governnient to show that the nunierous firms identified by Tenneco were not in fact equally likely entrants.

It therefore becomes critical, under the Areeda-Turner approach, to ascertain just how readily the defendants can enlarge the government's burden of proof. In a recent partial application of this approach, the FTC said that the defendants nuust be able to point to "objective factors" indicating that the designated firms in other markets will be "willing and able" to enter the target inarket. ${ }^{17}$ The FTC approach, however, does not answer the question of just how much evidence is necessary to inake the showing. If defendants are required to establish a full prima facie case that the additional inarkets identified are in equal or closer proximity im terms of entry-relevant factors than is the acquiring firm's market, the Areeda-Turner approach becoines roughly symmetrical with the pure proximity approach, with one important exception - the unwillingness of its two authors to close the

112. See supra text accompanying note 90.

113. Tenneco, 3 TRADE REG. ReP. (CCH) at 22,143.

114. See Comments of U.S. Dep't of Justice, supra note 83, at 32 (recommending deletion of the market attractiveness factor).

115. Tenneco, 3 Trade Reg. Rep. (CCH) at 22,151.

116. Id. at $22,149-50$.

117. See Heublem, Inc., 96 F.T.C. 385 (1980). 
door firmly on subjective evidence. ${ }^{18}$ These issues are not, however, critical in Tenneco, given the strength of the government's factual showing as articulated in the FTC opinion. Even if the burden of eliminating other inarkets was shifted to the government, the seeiningly decisive entry advantages favoring Tenneco would be outcomedeterminative on the issue of probable entry so long as the proof reinained primarily objective.

Thus, under the Tenneco facts, the two proximity approaches lead to a result similar to the analysis that I have suggested would be appropriate under the Guidelines. This is not surprising since their conceptual bases overlap; indeed the proximity approaches may provide useful initial standards for the undefined Guidelines concept of "entry advantage." The analysis also demonstrates that the decision whether to allow courts to consider subjective evidence will have a critical effect on the development of predictive legal standards. Only an approach that confines the analysis to objective economic facts can lead to a viable and effective enforcement rule for potential competition mergers.

\section{CONCLUSION}

The new Merger Guidelines attempt to revitalize potential competition inerger enforcement. In so doing the Guidelines make no radical change in enforcement policy, but clarify and simplify previous analytic approaches. This is desirable because as a result of cumbersone legal doctrines introduced by lower courts, potential competition enforcement has been ineffective in recent years, a condition that is contrary to the broad mandate of Congress and fundamental policies expounded by the Supreine Court. Although the Guidelines leave a key terin-entry advantage-undefined, that gap can be filled by using market proximity as a presumptive surrogate for entry advantage. Such a usage would reinforce the basic Guidelines' pohicy of mipleinenting a structural, unitary, and objective approach to potential competition merger enforceinent.

118. Certain other differeuces also remain. The Areeda-Turner approach makes no use of observed narket entry to confirm market similarity and would still require a showing of entry attractiveness. 